Original Article

\title{
A NOVEL VALIDATED UHPLC METHOD FOR ESTIMATION OF ASSAY AND ITS RELATED SUBSTANCES OF TRICHOSTATIN-A
}

\author{
L. VAIKUNTA RAO ${ }^{*}$, K. TIRUMALA RAO ${ }^{1,2}$, V. V. KRISHNA MOHAN KANDEPI ${ }^{2}$
}

${ }^{1}$ Department of Chemistry, Gitam Institute of Science, GITAM University (Deemed to be), Visakhapatnam 530045, India, ${ }^{2}$ Product and Technology Development, Eco Logic Technologies Ltd, Hyderabad 500072, India

Email: tirumalwithu@gmail.com

Received: 19 Feb 2020, Revised and Accepted: 21 May 2020

\section{ABSTRACT}

Objective: The main objective of the research work is to develop and validate a rapid UHPLC method for the estimation of assay and its related substances of Trichostatin A (TSA) in pharmaceutical samples.

Methods: The UHPLC method developed for chromatographic separation between TSA and its related compounds on Poroshell 120 SB C18(50×4.6) $\mathrm{mm} ; 2.7 \mu \mathrm{m}$ RRLC column using Agilent RRLC (UHPLC) system with linear gradient elution.

Results: The developed UHPLC method has shown excellent chromatographic separation between TSA and its related compounds within 12 min run time, during validation experiments, specificity study revealed that the peak threshold was more than the peak purity and no purity flag was observed. Repeatability, intra, and inter-day precision results were well within the tolerable limits. Limits of detection concentrations were found between 0.075 to $0.077 \mathrm{ppm}$ and the limit of quantitation is between 0.252 to $0.258 \mathrm{ppm}$ for related compounds and TSA. The related substances method recoveries were found between 80 and $120 \%$ and assay method recovery was found between 98.0 to $102.0 \%$.

Conclusion: The developed method capability was proven for the assay of TSA and its related compounds in pharmaceutical samples and the method shows eco-friendlier than routine, conventional HPLC methods in terms of analysis time, cost and HPLC effluent waste.

Keywords: Trichostatin A, Assay, Related substances, Method Validation, RRLC, UHPLC

(C) 2020 The Authors. Published by Innovare Academic Sciences Pvt Ltd. This is an open access article under the CC BY license (http://creativecommons.org/licenses/by/4.0/) DOI: http://dx.doi.org/10.22159/ijpps.2020v12i7.37198. Journal homepage: https://innovareacademics.in/journals/index.php/ijpps

\section{INTRODUCTION}

The HPLC method is an analytical method in which proving the separation-related impurities and its drug compound, and it helps to estimate the content of impurities and drugs to prove the quality of the drug substances [1-3]. In this study used UHPLC system and short column during development and the application of the UHPLC method is chromatographic method gained increasing importance because of their high selectivity, sensitivity and quick chromatographic separation method. In order to prove the quality of the drug substance being analyzed in sample solutions, it is necessary to measure the amount of impurities and drugs. By applying UHPLC concepts, it can reduce the run times of chromatographic methods and effluents and decrease the turnaround times [4-6]. Various UHPLC methods have been developed for the determination of related compounds and potency of the drug in pharmaceutical drug substances and formulations and many bioanalytical methods were developed to estimate the drug content in the pharmacy kinetic study and dietary samples [7-10].

Trichostatin A(TSA) is chemically known as, [R-(E,E)]-7-[4(Dimethylamino)phenyl]-N-hydroxy-4,6-dimethyl-7-0xo-2,4-heptadienamide (fig. 1). Trichostatin $\mathrm{A}$ is a hydroxamic acid. It has a role as a bacterial metabolite. It derives from a (R)-Trichostatic acid. TSA serves as an antifungal antibiotic and selectively inhibits the class I and II mammalian histone deacetylase (HDAC) families of enzymes, but not class III HDACs (i.e., sirtuins) $[11,12]$. It is a member of a larger class of histone deacetylase inhibitors (HDIs or HDACIs) that have a broad spectrum of epigenetic activities. Thus, TSA has some potential as an anti-cancer drug $[13,14]$.

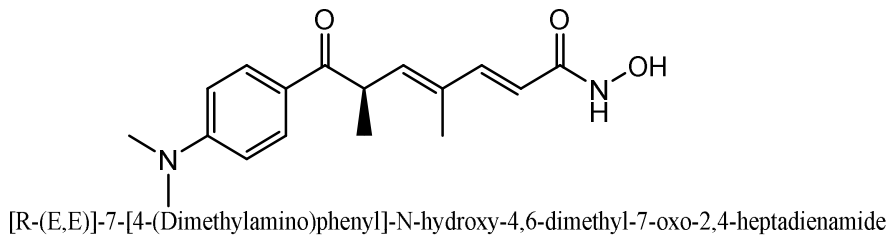

Chemical Formula: $\mathrm{C}_{17} \mathrm{H}_{22} \mathrm{~N}_{2} \mathrm{O}_{3}$

Molecular Weight: 302.37

Fig. 1: Chemical structure of trichostatin A (TSA)

TSA concentration was determined by high-performance liquid chromatography (HPLC)-UV assay (high dose) or by HPLC-multiple reaction monitoring assay (low dose) in plasma sample [15] and identification of the TSA by IEX-HPLC [16] and reported on stress studies of HDAC family compound YK-1101by HPLC-UV and HPLC-
TOF/MS methods [17] and also the majority of the reports were published on drug activity and metabolism [18-20].

Screening the literature, no related substances and assay method has been reported for the determination of TSA in pharmaceutical 
samples. In the current study, a simple, rapid and reliable lineargradient UHPLC method is developed for the estimation of related substances and assay of TSA in pharmaceutical samples. The recommended method is validated according to ICH guidelines [21, $22]$ and obtained results were meeting the desired criteria [23, 24] and established standard error.

\section{MATERIALS AND METHODS}

\section{Apparatus}

The ultra-high performance liquid chromatographic method (UHPLC) system was used model of Agilent 1260 Infinity series with a diode array detector (quaternary pump: G1311B, column thermostat: G1316B, Autosampler with cooler: G1329B and G1330B and detector: G4212B) for method development and validation, the chromatographic data was recorded, peak purity of the TSA was tested by using Chemstation DAD software (Agilent Technologies, Clara, US). A column Poroshell SB C18 50×4.6 mm; $2.7 \mu \mathrm{m}$ RRLC column manufactured by Agilent (Agilent Technologies, Clara, US) was procured from LCGC India.

\section{Materials}

Working standard of TSA procured from Merck, India and Active Pharma Ingredient (API) samples and related impurities (fig. 2) were taken from ecologic Research laboratory (Hyderabad, India), HPLC gradient grade acetonitrile, orthophosphoric acid, formic acid was used of HPLC grade manufactured by E. Merck was procured from a commercial source. HPLC grade water was obtained by a Millipore water purification system.

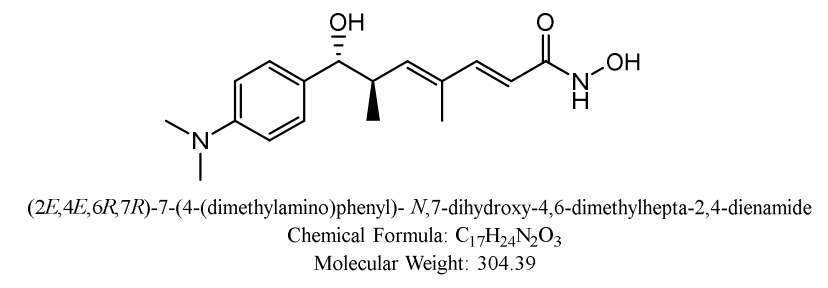

Chemical structure of Impurity-1<smiles>CNc1ccc(C(=O)[C@H](C)/C=C(C)/C=C/C(=O)NO)cc1</smiles>

(R,2E,4E)- $N$-hydroxy-4,6-dimethyl-7-(4-(methylamino)phenyl)-7-oxohepta-2,4-dienamide

Chemical Formula: $\mathrm{C}_{16} \mathrm{H}_{20} \mathrm{~N}_{2} \mathrm{O}_{3}$

Molecular Weight: 288.35

Chemical structure of Impurity-2<smiles>CC(/C=C/C(N)=O)=C\[C@H](C)C(=O)c1ccc(N(C)C)cc1</smiles>

[R-(E,E)]-7-[4-(Dimethylamino)phenyl]-4,6-dimethyl-7-oxohepta-2,4-dienamide

Chemical Formula: $\mathrm{C}_{17} \mathrm{H}_{22} \mathrm{~N}_{2} \mathrm{O}_{2}$

Molecular Weight: 286.38

Chemical structure of Impurity-3<smiles>CC(/C=C/C(=O)O)=C\[C@@H](C)C(=O)c1ccc(N(C)C)cc1</smiles>

[R-(E,E)]-7-[4-(Dimethylamino)phenyl]-4,6-dimethyl-7-oxohepta-2,4-dienoic acid

Chemical Formula: $\mathrm{C}_{17} \mathrm{H}_{21} \mathrm{NO}_{3}$

Molecular Weight: 287.36

Chemical structure of Impurity-4

Fig. 2: Chemical structure of related compounds of TSA

\section{Methods}

The UHPLC method [4] has developed for the chromatographic separation between TSA and its related compounds on Poroshell 120 SB C18 (50×4.6) mm; $2.7 \mu \mathrm{m}$ RRLC column using Agilent RRLC (UHPLC) system with linear gradient elution and the developed method was validated as per stated guidelines [21,24] to meet the suitability of the method and method development efforts, the outcome of validation experimental results are described in results and discussion section.

Preparation of standard solutions Standard solution

TSA standard solution $(500.65 \mu \mathrm{g} / \mathrm{ml})$ was prepared by accurately transferring $50.065 \mathrm{mg}$ into a $100 \mathrm{ml}$ volumetric flask. The 
compound was dissolved and diluted to the mark with diluent. The same solution was used for the assay determination.

\section{Impurities stock solutions}

TSA and related compound $5.03 \mu \mathrm{g} / \mathrm{ml}$ of TSA, $5.02 \mu \mathrm{g} / \mathrm{ml}$ of impurity-1, $5.12 \mu \mathrm{g} / \mathrm{ml}$ of impurity-2, $5.07 \mu \mathrm{g} / \mathrm{ml}$ of impurity- 3 and $5.17 \mu \mathrm{g} / \mathrm{ml}$ of impurity-4 stock solutions were prepared for the estimation of the related compound.

\section{Pharma samples for assay}

Sample solution $(500.55 \mu \mathrm{g} / \mathrm{ml})$ was prepared by accurately transferring the $50.055 \mathrm{mg}$ into $100 \mathrm{ml}$ volumetric flask and dissolved, diluted to the mark with diluent. This solution used for assay determination and related substances determination.

\section{RESULTS AND DISCUSSION}

\section{Method development}

The main objective of the method is to develop a rapid and single chromatographic method for the estimation of assay and its related compounds of TSA from pharmaceutical research lab samples. As TSA and related impurities are contained N-hydroxy, amide and acid functional groups and the compounds are would be in neutral and acidic nature; therefore, the development trials were attempted under acidic conditions by taking mobile phase with formic acid, Trifluoroacetic acid and orthophosphoric acid on three different C18 columns. At these chromatographic conditions, Waters X-terra MS C18, X-Bridge C18 column resolution between TSA and impurity-3 is co-eluted both pairs, whereas Poroshell SB C18 column good resolution was observed under Trifluoroacetic acid and Formic acid conditions, but baseline noise is more, and it can't be attained sensitivity for the related compounds. Therefore, the ortho- phosphoric acid mobile phase is chosen for the method optimization on the same column.

\section{Optimized chromatographic conditions}

The chromatographic separation was achieved on Poroshell SBC18 UHPLC/RRLC column $(50 \times 4.6 \mathrm{~mm} ; 2.7 \mu \mathrm{m})$ using mobile phase A as $0.1 \% \mathrm{v} / \mathrm{v}$ orthophosphoric acid and mobile phase $\mathrm{B}$ as acetonitrile with a linear gradient program: time $(\mathrm{min}) / \% \mathrm{~B}$ is $0 / 10,7 / 65,8 / 10$, and $12 / 40$ at a flow rate of $0.6 \mathrm{ml} / \mathrm{min}$ and the column temperature was maintained at $25{ }^{\circ} \mathrm{C}$ using $5.0 \mu$ injection volume. Related impurities and TSA were monitored at $272 \mathrm{~nm}$ UV detection and the diluent solution was prepared as water, acetonitrile and formic acid ratio 65:35:0.1 for standard and sample solution preparations.

\section{Method validation}

\section{Specificity/selectivity}

Specificity is to the ability to measure accurately and specifically the analyte of interest in the presence of other components that may be expected to be present in the sample matrix [21-25]. Specificity of the method was evaluated by injecting the blank, individual-related compounds and sample solution prepared by spiking related compounds of TSA at $0.1 \%$ level of test concentration used as system suitability check to verify the co-elution between peaks. The outcome of the specificity and system suitability test revealing that there was no interference from the blank peaks eluted at related compounds and TSA. The peak purity data shows the peaks are homogeneous and there was no co-eluting peak at the retention time of TSA peak and related compound peaks. The system suitability test results are given in table 1 and 2 and typical blank and system suitability (specificity) chromatograms are given in fig. 3 and 4 , respectively.

Table 1: System suitability test (SST-1) results for related substances method

\begin{tabular}{|c|c|c|c|c|}
\hline Name & Retention time (tR) in min & USP resolution (Rs) & USP theoretical plates (N) & USP tailing factor (T) \\
\hline Impurity-1 & 5.260 & & 39401 & 1.18 \\
\hline Impurity-2 & 6.22 & 8.63 & 45619 & 1.90 \\
\hline Trichostatin A (TSA) & 6.97 & 6.36 & 53673 & 1.62 \\
\hline Impurity-3 & 7.44 & 3.98 & 68598 & 1.11 \\
\hline Impurity-4 & 8.35 & 7.42 & 65102 & 1.87 \\
\hline
\end{tabular}

$\mathrm{n}=1$ injection

Table 2: System suitability test (SST-2 and 3) results

\begin{tabular}{lll}
\hline $\begin{array}{l}\text { System suitability test (SST-2) } \\
\text { substances method }\end{array}$ & name precision $(\mathbf{n}=\mathbf{6})$ results for related & $\begin{array}{l}\text { System suitability test (SST-2) precision (n=6) results for } \\
\text { the assay method }\end{array}$ \\
\hline Injection & Area of TSA $(0.5 \mu \mathrm{g} / \mathrm{ml})$ & Area of TSA $(500 \mu \mathrm{g} / \mathrm{ml})$ \\
Injection-1 & 10392 & 6882925 \\
Injection-2 & 11393 & 6943811 \\
Injection-3 & 10894 & 6970781 \\
Injection-4 & 11147 & 6933587 \\
Injection-5 & 10512 & 6920611 \\
Injection-6 & 10987 & 6896385 \\
mean \pm SD & $10887.5 \pm 379.3$ & $6924683.3 \pm 32035.2$ \\
\%RSD & 3.48 & 0.46 \\
\hline
\end{tabular}

$\mathrm{n}=6$ injections

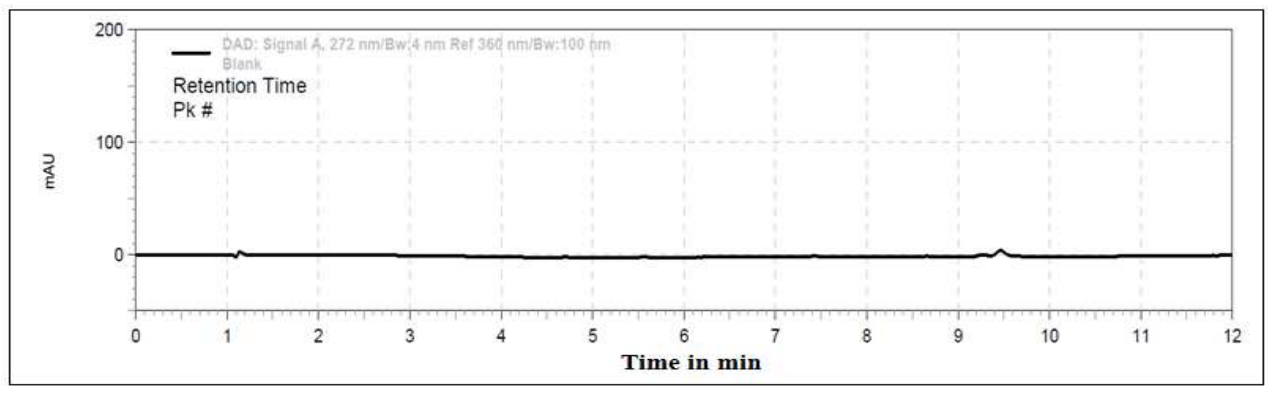

Fig. 3: A typical blank chromatogram 


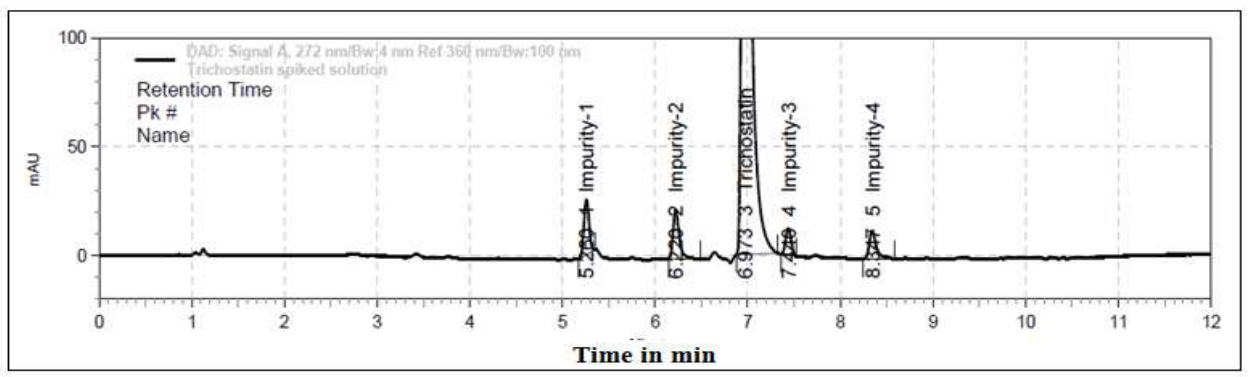

Fig. 4: A system suitability chromatogram

\section{Precision}

Precision of an analytical procedure is determined by assaying a sufficient number of aliquots of a homogeneous sample to be able to calculate statistically valid estimates of standard deviation or relative standard deviation [21]. For related compound method, six solutions containing TSA $(500 \mu \mathrm{g} / \mathrm{ml})$ were spiked with related compounds solutions $0.5 \mu \mathrm{g} / \mathrm{ml}$ (a $0.10 \%$ of TSA concentration). Chromatography was performed and value of \%RSD was calculated considering peak area for TSA and each related compound. Similarly, intermediate precision of the method was also evaluated by another analyst, on a different day in the same laboratory.
For assay method, six individual sample solutions were prepared TSA $(500 \mu \mathrm{g} / \mathrm{ml})$ and calculated assay of the compound against standard solution and also checked \%RSD for assay values for six determinations. Similarly, intermediate precision of the method was also evaluated by another analyst, on a different day in the same laboratory.

The outcome from the precision is showing for assay method is below $0.6 \%$ and related substances method is below $1.0 \%$ and as per FDA guideline stated that precision of method for assay should be less than $2 \%$ and the results are meeting the criteria [24] also calculated 95\% confidence level and mean \pm standard error and the observed results are given in below table 2 .

Table 2: Precision results

\begin{tabular}{lllll}
\hline Analyte/impurity & TSA & Impurity-1 & Impurity-2 & Impurity-3 \\
\hline Mean & 99.0 & 0.24 & 0.28 & 0.25 \\
STDEV $(\sigma)$ & 0.51 & 0.02 & 0.01 & 0.00 \\
\%RSD & 0.52 & 6.36 & 1.99 & 0.20 \\
CI at 95\% & $99.0 \pm 0.408$ & $0.24 \pm 0.016$ & $0.28 \pm 0.004$ & 0.01 \\
mean \pm SE & $99.0 \pm 0.208$ & $0.24 \pm 0.008$ & $0.28 \pm 0.002$ & $0.25 \pm 0.003$ \\
\hline
\end{tabular}

${ }^{*} \mathrm{n}=6$ six determinations, $0.15 \%$ level impurities with respect to analyte concentration $(500 \mu \mathrm{g} / \mathrm{ml}), 100 \%$ level at assay conc.500 $\mu \mathrm{g} / \mathrm{ml}$ of TSA, CIConfidence interval, SE-standard error

\section{Limit of detection and limit of quantitation}

Limit of detection (LOD) of an individual procedure is the lowest amount of analyte in a sample that can be detected but not necessarily quantitated as an exact value. In analytical procedures that exhibit baseline noise, the LOD can be based on a signal-to-noise $(\mathrm{S} / \mathrm{N})$ ratio (3:1), which is usually expressed as the concentration of an analyte in the sample. The signal-to-noise ratio is determined by: $\mathrm{s}=\mathrm{H} / \mathrm{h}$ Where $\mathrm{H}=$ height of the peak corresponding to the component. $\mathrm{h}=$ absolute value of the largest noise fluctuation from the baseline of the chromatogram of a blank solution. The limit of Quantitation (LOQ) or Quantitation limit of an individual analytical procedure is the lowest amount of analyte in a sample that can be quantitatively determined with suitable precision and accuracy. For analytical procedures such as HPLC that exhibit baseline noise, the LOQ is generally estimated from a determination of $\mathrm{S} / \mathrm{N}$ ratio $(10: 1)$ and is usually confirmed by injecting standards which give this $\mathrm{S} / \mathrm{N}$ ratio and have an acceptable percent relative standard deviation as well [24].

The proposed related substances method was checked for the method sensitivity for all related compounds and analyte, which shows excellent sensitivity and meeting to reporting threshold requirement (i.e., $\leq 0.05 \%$ level) [22]. LOQ precision and accuracy also executed and precision at LOQ level is shows $<10 \%$ RSD and it is meeting to the acceptance criteria [23] and accuracy at LOQ level is described at accuracy parameter. The details of LOD, LOQ is given in table 3 and representative LOD and LOQ chromatograms are in fig. 5 and 6.

Table 3: LOD and LOQ for related substances method

\begin{tabular}{|c|c|c|c|c|c|}
\hline Parameter & Impurity-1 & Impurity-2 & Impurity-3 & Impurity-4 & TSA \\
\hline LOD conc. $(\mu \mathrm{g} / \mathrm{ml})$ & 0.075 & 0.077 & 0.076 & 0.077 & 0.075 \\
\hline LOQ conc. $(\mu \mathrm{g} / \mathrm{ml})$ & 0.251 & 0.256 & 0.254 & 0.258 & 0.252 \\
\hline LOQ precision ( $\%$ RSD for $n=6)$ & 5.4 & 6.1 & 5.7 & 7.9 & 3.9 \\
\hline
\end{tabular}

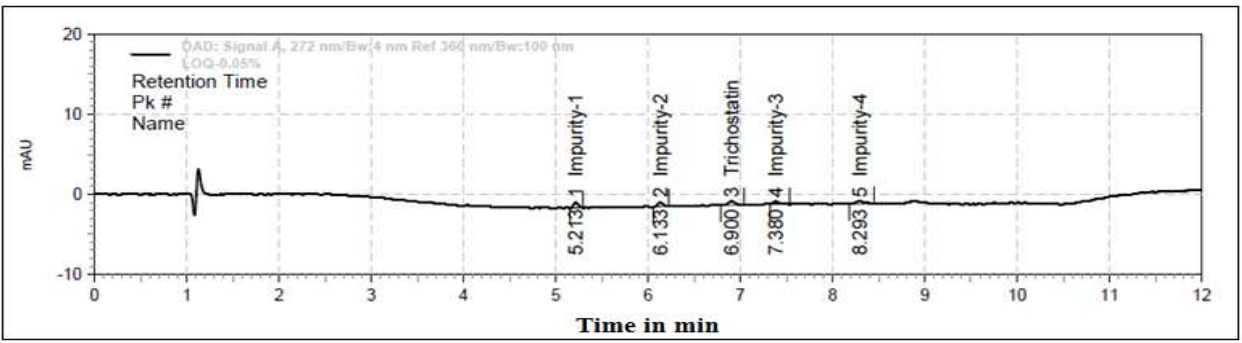

Fig. 5: Typical LOD chromatogram 


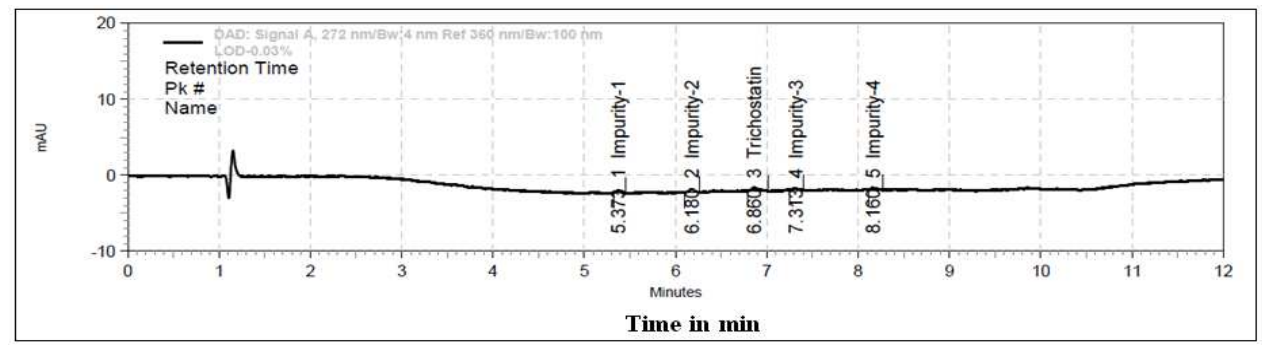

Fig. 6: Typical LOQ chromatogram

\section{Linearity}

The linearity of an analytical procedure is its ability (within a given range) to obtain test results, which are directly proportional to the concentration of an analyte in the sample. For the establishment of linearity, a minimum of five concentrations are recommended by ICH guidelines [21].

For the related compound determination method, linearity was checked for related compounds and TSA at lower concentration levels $0.05 \%$ to $0.25 \%$ (i.e., $0.25 \mu \mathrm{g} / \mathrm{ml}$ to $1.25 \mu \mathrm{g} / \mathrm{ml}$ ). The responses were measured as peak areas and plotted against concentration. The similar experiment was performed for assay method linearity by preparing the standard concentrations $80 \%$ to $120 \%$ at assay concentration level (i.e., $400 \mu \mathrm{g} / \mathrm{ml}$ to $600 \mu \mathrm{g} / \mathrm{ml}$ ).
The calibration curve was drawn by plotting each impurity peak area versus its corresponding concentration. The correlation coefficient, slope, y-intercept, slope \pm SE calculated for each impurity and TSA were determined. Results are given in below table 4 and 5; linearity plots are given in fig. 7 .

The outcome for the related substances method data shows, the correlation and regression co-efficient values are greater than 0.995 and these are well within the acceptable criteria $[23,24]$ and the standard error shows within $3 \%$ of slope value. For the assay method obtained data shows, correlation and regression co-efficient values are greater than 0.995 , which is well with acceptance criteria and standard error shows with $0.15 \%$ of slope value. It reveals that both proposed methods are linear.

Table 4: Linearity data of related substances method

\begin{tabular}{|c|c|c|c|c|c|c|c|c|c|}
\hline \multicolumn{2}{|l|}{ Impurity-1 } & \multicolumn{2}{|l|}{ Impurity-2 } & \multicolumn{2}{|l|}{ Impurity-3 } & \multicolumn{2}{|l|}{ Impurity-4 } & \multicolumn{2}{|l|}{ TSA } \\
\hline $\begin{array}{l}\text { Conc. } \\
\mu \mathrm{g} / \mathrm{ml}\end{array}$ & Area & $\begin{array}{l}\text { Conc. } \\
\mu \mathrm{g} / \mathrm{ml}\end{array}$ & Area & $\begin{array}{l}\text { Conc. } \\
\mu \mathrm{g} / \mathrm{ml}\end{array}$ & Area & $\begin{array}{l}\text { Conc. } \\
\mu \mathrm{g} / \mathrm{ml}\end{array}$ & Area & $\begin{array}{l}\text { Conc. } \\
\mu \mathrm{g} / \mathrm{ml}\end{array}$ & Area \\
\hline 0.251 & 5091 & 0.256 & 4183 & 0.254 & 3466 & 0.258 & 4859 & 0.252 & 5170 \\
\hline 0.251 & 5498 & 0.256 & 4095 & 0.254 & 3612 & 0.258 & 4951 & 0.252 & 5287 \\
\hline 0.502 & 9373 & 0.512 & 8269 & 0.507 & 8415 & 0.515 & 11429 & 0.503 & 11005 \\
\hline 0.502 & 9879 & 0.512 & 9006 & 0.507 & 8697 & 0.515 & 10931 & 0.503 & 11393 \\
\hline 0.753 & 15431 & 0.768 & 13197 & 0.761 & 13478 & 0.753 & 15987 & 0.755 & 16582 \\
\hline 0.753 & 15065 & 0.768 & 12897 & 0.761 & 12745 & 0.753 & 16238 & 0.755 & 16931 \\
\hline 1.004 & 20005 & 1.024 & 16785 & 1.014 & 17102 & 1.030 & 21287 & 1.006 & 21412 \\
\hline 1.004 & 19875 & 1.024 & 16982 & 1.014 & 16997 & 1.030 & 21299 & 1.006 & 21785 \\
\hline 1.255 & 24333 & 1.280 & 20302 & 1.268 & 22104 & 1.288 & 27412 & 1.258 & 26311 \\
\hline 1.255 & 24587 & 1.280 & 21006 & 1.268 & 21897 & 1.288 & 27854 & 1.258 & 26782 \\
\hline $\begin{array}{l}\text { Correlation } \\
\text { (r) }\end{array}$ & 0.9989 & $\begin{array}{l}\text { Correlation } \\
(\mathrm{r})\end{array}$ & 0.9982 & $\begin{array}{l}\text { Correlation } \\
\text { (r) }\end{array}$ & 0.9988 & $\begin{array}{l}\text { Correlation } \\
\text { (r) }\end{array}$ & 0.9987 & $\begin{array}{l}\text { Correlation } \\
\text { (r) }\end{array}$ & 0.9987 \\
\hline $\begin{array}{l}\text { Regression } \\
\text { (r2) }\end{array}$ & 0.9978 & $\begin{array}{l}\text { Regression } \\
\text { (r2) }\end{array}$ & 0.9965 & $\begin{array}{l}\text { Regression } \\
\text { (r2) }\end{array}$ & 0.9977 & $\begin{array}{l}\text { Regression } \\
\text { (r2) }\end{array}$ & 0.9974 & $\begin{array}{l}\text { Regression } \\
\text { (r2) }\end{array}$ & 0.9973 \\
\hline Slope (m) & 19380.5 & Slope (m) & 16123.4 & Slope (m) & 17915.8 & Slope (m) & 21573.6 & Slope (m) & 21087.7 \\
\hline $\begin{array}{l}y \text {-interccept } \\
\text { (c) }\end{array}$ & 320.2 & $\begin{array}{l}y \text {-interccept } \\
\text { (c) }\end{array}$ & 289.4 & $\begin{array}{l}y \text {-interccept } \\
\text { (c) }\end{array}$ & -773.7 & $\begin{array}{l}\text { y-interccept } \\
\text { (c) }\end{array}$ & -356.8 & $\begin{array}{l}y \text {-interccept } \\
\text { (c) }\end{array}$ & 355.2 \\
\hline Slope $\pm S E$ & $\begin{array}{l}19380.5 \pm 361 \\
.2\end{array}$ & Slope $\pm S E$ & $\begin{array}{l}16123.4 \pm 387 \\
.9\end{array}$ & Slope $\pm S E$ & $\begin{array}{l}17915.8 \pm 345 \\
.0\end{array}$ & Slope $\pm S E$ & $\begin{array}{l}21573.6 \pm 452 \\
.4\end{array}$ & Slope $\pm S E$ & $\begin{array}{l}21087.7 \pm 433 \\
.3\end{array}$ \\
\hline
\end{tabular}

$\mathrm{n}=2$ injections at each level

Table 5: Linearity data of assay method

\begin{tabular}{ll}
\hline TSA & \\
\hline Conc. $(\boldsymbol{\mu g} / \mathbf{m l})$ & Area \\
\hline 400.26 & 5504257 \\
400.26 & 5533835 \\
450.59 & 6191429 \\
450.59 & 6213440 \\
500.65 & 6878601 \\
500.65 & 6824561 \\
550.72 & 7565085 \\
600.79 & 7590536 \\
600.79 & 8278396 \\
Correlation (r) & 8319668 \\
Regression (r2) & 0.9996 \\
Slope (m) & 0.9992 \\
y-interccept (c) & 13838 \\
Slope \pm SE & -37144 \\
\hline
\end{tabular}

$n=2$ injections at each level 


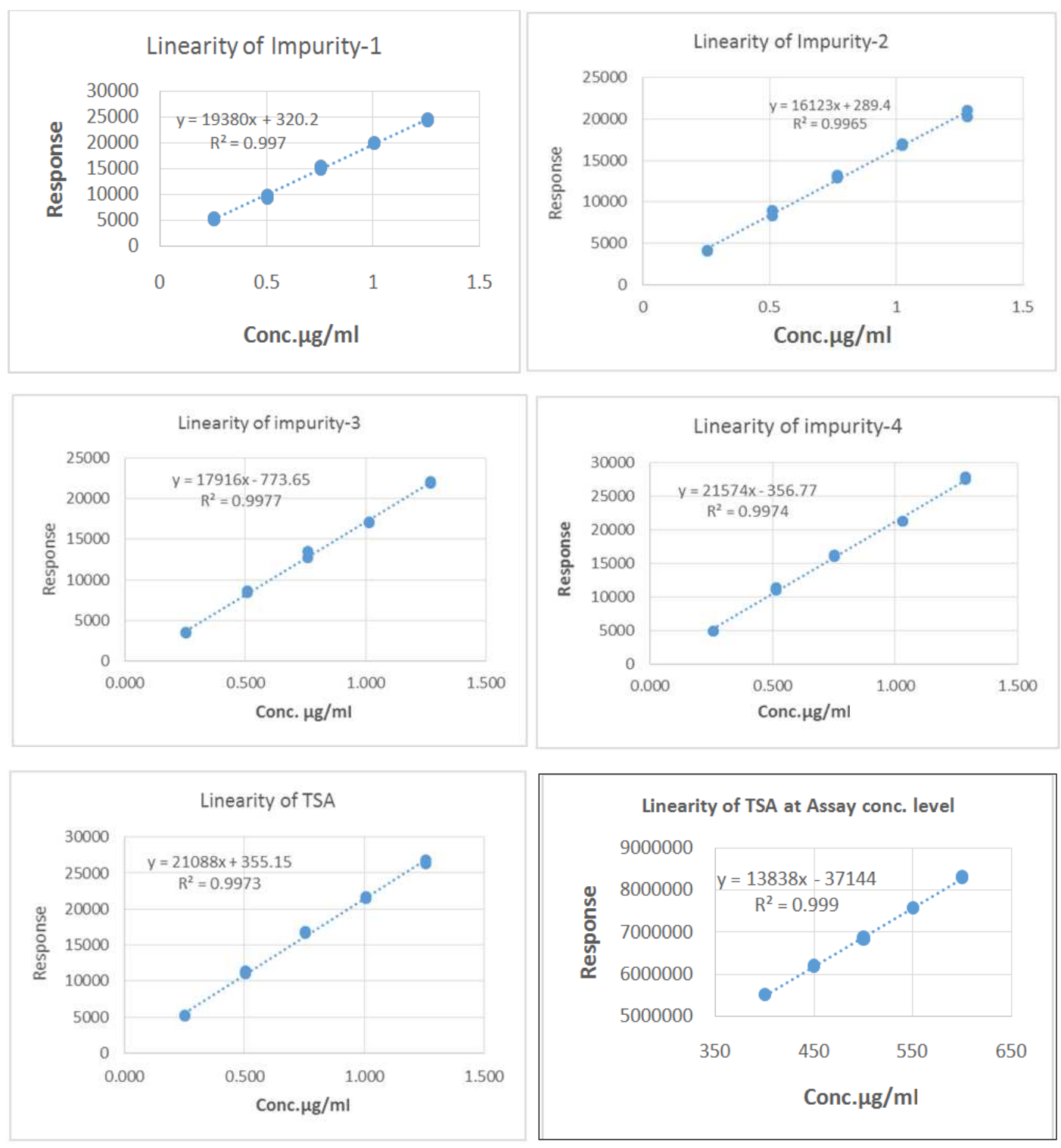

Fig. 7: Linearity plots of related substances method and assay method

\section{Accuracy}

Accuracy is the agreement between the test results obtained by the proposed method and the true value. It expresses the correctness of the method. It is expressed as a percentage by the assay of a known amount of substance. Accuracy also evaluated by recovery studies, in which a known amount of drug is added to previously analyzed pharmaceutical preparation of the drug and tested for the recovery of the added drug [23-27].

The absolute error is a measure of the accuracy of the measurement; it is then calculated as given in Equation-1

$$
\begin{aligned}
\text { Absolute error }= & \text { Mean error } \times \frac{\text { True value }- \text { Measured value }}{\text { True value }} \\
& \times 100 \text { Equation }-1
\end{aligned}
$$

The accuracy of the assay method was evaluated in triplicate $(n=3)$ at the concentration levels of TSA 400,500 and $600 \mu \mathrm{g} / \mathrm{ml}(80 \%$, $100 \%$ and $120 \%$ ) and the \% recovery was calculated at each level and the recoveries were observed between $99.5 \%$ to $100.3 \%$. These are well within the acceptance criterion for assay method i.e., 98.0 to $102.0 \%$ [24] and which indicated that the proposed assay method is accurate. Results are given in table 6 and 7.

Table 6: Accuracy results of an assay method

\begin{tabular}{llll}
\hline Name & \% Level & Amount added $(\boldsymbol{\mu g} / \mathbf{m l})$ & Amount found $(\boldsymbol{\mu g} / \mathbf{m l})$ \\
\hline TSA $^{\#}$ & 80 & 400.26 & 401.53 \\
& 100 & 500.65 & 497.83 \\
Mean & 120 & 600.79 & 602.43 \\
Std dev $(\sigma)$ & & & 100.3 \\
mean \pm SE & & & 100.3 \\
\% RSD & & & 0.50 \\
\end{tabular}

\#Assay concentration level recovery, $\mathrm{n}=3$ determination at each level 
Similarly, accuracy of the related substances method evaluated in triplicate $(n=3)$ at the concentration levels of each related compound $0.05 \%, 0.15 \%$ and $0.25 \%$ level and the \% recovery was calculated for each related compound and the recoveries were found between $91.5 \%$ to $98.5 \%$ which are well between acceptance criteria i.e., 80.0 to $120.0 \%$. The proposed related substances method is accurate.

Table 7: Accuracy results of related substances method

\begin{tabular}{|c|c|c|c|c|}
\hline Name & \% Level & Amount added $(\mu \mathrm{g} / \mathrm{ml})$ & Amount found $(\mu \mathrm{g} / \mathrm{ml})$ & \% Recovery \\
\hline \multirow{3}{*}{ Impurity-1 } & LOQ & 0.251 & 0.241 & 96.02 \\
\hline & $0.15 \%$ & 0.753 & 0.695 & 92.30 \\
\hline & $0.25 \%$ & 1.255 & 1.201 & 95.70 \\
\hline Mean & & & & 94.67 \\
\hline Std $\operatorname{dev}(\sigma)$ & & & & 2.06 \\
\hline mean $\pm S E$ & & & & $94.67 \pm 1.19$ \\
\hline$\%$ RSD & & & & 2.2 \\
\hline \multirow[t]{3}{*}{ Impurity-2 } & LOQ & 0.256 & 0.247 & 96.48 \\
\hline & $0.15 \%$ & 0.768 & 0.714 & 92.97 \\
\hline & $0.25 \%$ & 1.280 & 1.214 & 94.84 \\
\hline Mean & & & & 94.77 \\
\hline Std $\operatorname{dev}(\sigma)$ & & & & 1.76 \\
\hline mean $\pm \mathrm{SE}$ & & & & $94.77 \pm 1.02$ \\
\hline$\%$ RSD & & & & 1.9 \\
\hline \multirow[t]{3}{*}{ Impurity-3 } & LOQ & 0.254 & 0.245 & 96.46 \\
\hline & $0.15 \%$ & 0.761 & 0.689 & 90.54 \\
\hline & $0.25 \%$ & 1.268 & 1.223 & 96.45 \\
\hline Mean & & & & 94.48 \\
\hline Std $\operatorname{dev}(\sigma)$ & & & & 3.42 \\
\hline mean $\pm S E$ & & & & $94.48 \pm 1.97$ \\
\hline$\%$ RSD & & & & 3.6 \\
\hline \multirow[t]{3}{*}{ Impurity-4 } & LOQ & 0.258 & 0.241 & 93.41 \\
\hline & $0.15 \%$ & 0.753 & 0.699 & 92.83 \\
\hline & $0.25 \%$ & 1.288 & 1.238 & 96.12 \\
\hline Mean & & & & 94.12 \\
\hline Std $\operatorname{dev}(\sigma)$ & & & & 1.76 \\
\hline mean $\pm S E$ & & & & $94.12 \pm 1.01$ \\
\hline$\%$ RSD & & & & 1.9 \\
\hline
\end{tabular}

$\mathrm{n}=3$ determinations at each level

\section{Stability of the solution}

A sample solution of assay method and related substance method was checked at different time intervals up to $48 \mathrm{~h}$ by keeping solution at room temperature and checked cumulative \%RSD for the peak area of TSA and its related compounds. The \%RSD of TSA and its related compound peak areas were found be less than $1 \%$ and $8 \%$, respectively. The stability of TSA sample solution in both proposed methods is stable up to $48 \mathrm{~h}$.

\section{CONCLUSION}

The proposed linear-gradient UHPLC method is simple, rapid and selective and it was satisfying to all verified validation parameters, it indicates that the method is specific, precise, linear and accurate. In this method, TSA and its related compounds were eluted within 12 min run time of chromatographic elution and it shows very excellent turnaround time (TAT) outcome of the analysis. The developed method shows ecofriendly when compared to regular conventional HPLC methods in terms of effluent load, analysis cost, energy cost. Therefore, the developed method is more suitable for the quantification of TSA and its related compounds in pharmaceutical samples; hence the proposed method is recommended to use research and pilot-scale laboratories.

\section{ACKNOWLEDGMENT}

The author is thankful to Asst. Prof. Vaikunta Rao. L Department of chemistry, GITAM institute of science, GITAM (deemed to be) University for his continues guidance and support.

\section{FUNDING}

Nil

\section{AUTHORS CONTRIBUTIONS}

V. V. Krishna Mohan Kandepi has supported for the impurities and samples from the process research group of ecologic technologies limited and K. Tirumala Rao has designed, planned and performed experiments, measurements. He processed the experimental data along with calculations and interpreted the results, drafted the manuscript and reviewed and suggestions and comments were given by both authors. Author is also thankful to ecologic technologies provided the support of this research work. We would also thank our colleagues of the Analytical Research department of ecoLogic Technologies Ltd for their support.

\section{CONFLICT OF INTERESTS}

The authors declare that there are no conflicts of interest regarding the publication of this paper.

\section{REFERENCES}

1. Ahuja S, Dong M. Handbook of pharmaceutical analysis by HPLC. 1st ed. Amsterdam: Elsevier; 2005.

2. Snyder LR, Kirkland JJ, Glajch JL. Practical HPLC method development. 2nd ed. Hoboken: John Wiley and Sons, Inc.; 1997.

3. Shivani S, Swapnil G, Kalindi C. A review on analytical method development and validation. Int J Appl Pharm 2018;10:6.

4. Lutfun N, Alev 0, Satyajit DS. A review on the recent advances in HPLC, UHPLC and UPLC analyses of naturally occurring cannabinoids (2010-2019). Phytochem Anal 2019;1-45. Doi:10.1002/pca.2906

5. Judyta CP, Przemysław Z, Anna J, Piotr G. UHPLC: the greening face of liquid chromatography. Chromatographia 2013;76:1429-37.

6. Narwate BM, Ghule PJ, Ghule AV, Darandale AS, Wagh JG. Ultra performance liquid chromatography: a new revolution in liquid chromatography. Int J Pharm Drug Anal 2014;2:25-34.

7. Venu B, Siva RT, Krishna MT, Bhanu TS, Parmita M. Development and validation of stability indicating UPLCPDA/MS for the determination of Imiquimod and its eight related substances: application to a topical cream. J Chromatographic Sci 2019;57:249-57. 
8. Peterka TR. Forced degradation of tacrolimus and the development of a UHPLC method for impurities determination. Acta Pharm 2019;69:3.

9. Jayshri RK, Amitkumar JV, Bhupatsinh V, Parth P, Ashok P. DAD Based stability-indicating RP-UPLC method for simultaneous determination of olmesartanmedoxomil and amlodipine besylate. Pharm Chem J 2019;52:959-64.

10. Mohsin K, Abdulmohsen AA, Badr SA, Musaed A, Fars KA. UHPLC method development for determining sitagliptin and dapagliflozin in lipid-based self-nanoemulsifying systems as combined dose in commercial products and its application to pharmacokinetic study of dapagliflozin in rats. Pharm Chem J 2019;53:79-87.

11. Vanhaejcke T, Papeleu P, Elaut G, Rogiers V. Trichostatin a-like hydroxamate histone deacetylase inhibitors as therapeutic agents: toxicological point of view. Curr Med Chem 2004;11:1629-43.

12. You W, Steegborn C. Structural basis of sirtuin 6 inhibition by the hydroxamate trichostatin a: implications for protein deacylase drug development. J Med Chem 2018;61:10922-8.

13. Drummond DC, Noble CO, Kirpotin DB, Guo Z, Scott GK, Benz CC. Clinical development of histone deacetylase inhibitors as anticancer agents. Annu Rev Pharmacol Toxicol 2005;45:495-528.

14. Shankar S, Srivastava RK. Histone deacetylase inhibitors: mechanisms and clinical significance in cancer: HDAC inhibitorinduced apoptosis. Adv Exp Med Biol 2008;615:261-98.

15. Sanderson L, Taylor GW, Aboagye EO, Alao JP, Latigo JR, Coombes RC, et al. Plasma pharmacokinetics and metabolism of the histone deacetylase inhibitor trichostatin an after intraperitoneal administration to mice. Drug Meta Dispos 2004;32:1132-8.

16. Chan JN, Vuckovic D, Sleno L, Olsen JB, Pogoutse O, Havugimana $\mathrm{P}$, et al. Target identification by chromatographic co-elution: monitoring of drug-protein interactions without immobilization or chemical derivatization. Mol Cell Proteomics 2012;11:M111.016642.

17. Chen Z, Wen Yuan L, Feng F, Hai Y, Chun Yong W. Determination and stress studies on YK-1101, a potential histone deacetylase, by HPLC-UV and HPLC-TOF/MS methods. J Pharm Anal 2013;3:168-72.

18. Jeon HG, Yoon CY, Yu JH, Park MJ, Lee JE, Jeong SJ, et al. Induction of caspase-mediated apoptosis and down-regulation of nuclear factor-kB and Akt signaling are involved in the synergistic antitumor effect of gemcitabine and the histone deacetylase inhibitor trichostatin a in human bladder cancer cells. J Urol 2011;186:2084-93.

19. Li GC, Zhang X, Pan TJ, Chen Z, Ye ZQ. Histone deacetylase inhibitor trichostatin A inhibits the growth of bladder cancer cells through the induction of p21WAF1 and G1 cell cycle arrest. Int J Urol 2006;13:581-6.

20. Ozawa A, Tanji N, Kikugawa T, Sasaki T, Yanagihara Y, Miura N, et al. Inhibition of bladder tumour growth by histone deacetylase inhibitor. BJU Int 2010;105:1181-6.

21. ICH: Validation of analytical procedures: text and methodology, International Conference on Harmonization Guidance Documents; 2005;Q2(R1).

22. ICH: Impurities in new drug substances: international conference on harmonization guidance documents; 2006;Q3A(R1).

23. FDA. Reviewer guidance validation of chromatographic methods. CDER; 1994.

24. Shabir GA. Validation of high-performance liquid chromatography methods for pharmaceutical analysis. Understanding the differences and similarities between validation requirements of the US Food and Drug Administration, the US Pharmacopeia and the International Conference on Harmonization. J Chromatogr A 2003;987:57-66.

25. Gupta V, Ajay DKJ, Gill NS, Kapil G. Development and validation of HPLC method-a review. Int Res J Pharm Appl Sci 2012:2:17-25.

26. Charde MS, Welankiwar AS, Kumar J. Method development by liquid chromatography with validation. Int J Pharm Chem 2014;4:57-61.

27. Bhagyasree $\mathrm{T}$, Injeti $\mathrm{N}$, Azhakesan $\mathrm{A}$, Rao UM. A review on analytical method development and validation. Int J Pharm Res Anal 2014;4:444-8. 